\title{
PERAN SELF REGULATED LEARNING DAN KONSEP DIRI TERHADAP PRESTASI AKADEMIK MAHASISWA REMAJA AKHIR FAKULTAS KEDOKTERAN UNIVERSITAS UDAYANA YANG PERNAH MENJADI FINALIS BALI PAGEANTS Syntia Agung Liana Puspita dan I Made Rustika \\ Program Studi Psikologi, Fakultas Kedokteran, Universitas Udayana \\ syntiaagung@gmail.com
}

\begin{abstract}
Abstrak
Pencapaian prestasi akademik yang tinggi merupakan kebutuhan yang sangat penting bagi remaja yang pernah mengikuti ajang Bali Pageants. Keberhasilan mencapai prestasi yang tinggi berkaitan dengan self regulated learning dan juga konsep diri. Self regulated learning adalah kemampuan individu untuk mengatur disiplin diri dalam belajar, sedangkan konsep diri merupakan kemampuan seorang menilai kekuatan dan kelemahan dalam diri. Penelitian ini bertujuan untuk mengetahui peran self regulated learning dan konsep diri terhadap prestasi akademik pada mahasiswa remaja akhir. Subjek yang digunakan dalam penelitian ini adalah mahasiswa remaja akhir FK UNUD yang pernah menjadi finalis ajang Bali Pageants. Hasil uji regresi berganda adalah $\mathrm{R}=0,385$ dan koefisien determinasi sebesar 0,148. Hal ini menunjukkan variabel self regulated dan konsep diri secara bersama-sama berperan sebesar 14,8\% terhadap prestasi akademik. Koefisien beta terstandarisasi self regulated learning sebesar 0,405 dan signifikansi 0,012 $(\mathrm{p}<0,05)$ menunjukkan self regulated learning berperan secara signifikan terhadap prestasi akademik. Koefisien beta terstandarisasi konsep diri sebesar -0,034 dan signifikansi 0,827 ( $p>0,05)$ menunjukkan konsep diri tidak berperan terhadap prestasi akademik.
\end{abstract}

Kata kunci: prestasi akademik, self regulated learning, konsep diri, remaja akhir, finalis Bali Pageants

\begin{abstract}
High academic achievement is a important needs for adolescents who joined Bali Pageants event. A success to get high academic achievement is related with self regulated learning and self concept. Self regulated learning is how people dicipline themselves when study, therefore self concept is how people judge their strength and weakness. This study aimed to explore the role of self regulated learning and self concept to the academic achievement in late adolescent students. The subject for this study are late adolescent students of Faculty of Medicine Udayana University who was a finalist in Bali Pageants. The results of multiple regression analysis is $\mathrm{R}=0,385$ and $\mathrm{R} 2=0,148$. This shows that variable of self regulated learning and self concept conjunctly contributes as much as $14,8 \%$ to academic achievement. Standardized beta coefficient of self regulated learning showed the value of 0,45 and significance 0,012 $(\mathrm{p}<0.05)$, which concluded that a self regulated learning is contribute to the academic achievement. Standardized beta coefficient of self concept showed the value of $-0,034$ and significance 0,827 ( $p>0.05$ ), which concluded that a self concept doesn't contribute to the academic achievement.
\end{abstract}

Keyword: academic achievement, self regulated learning, self concept, late adolescents, Bali Pageants finalist. 


\section{S. A. L. PUSPITA DAN I M. RUSTIKA}

\section{LATAR BELAKANG}

Prestasi akademik merupakan suatu pencapaian yang penting dalam bidang pendidikan. Prestasi akademik adalah hasil evaluasi dari suatu proses belajar yang biasanya dinyatakan dalam bentuk kuantitatif (angka) yang khusus dipersiapkan untuk proses evaluasi misalnya nilai pelajaran, mata kuliah, nilai ujian dan lain sebagainya (Suryabrata, 1993). Memasuki tingkatan pendidikan di sekolah, prestasi akademik seperti nilai rapor dan ranking di dalam kelas menjadi hal yang begitu berarti pada sebagian besar siswa. Menurut Nurman (dalam Siregar, 2006) mutu output mahasiswa dari suatu jenjang pendidikan dapat dilihat dari prestasi belajar seseorang. Kedudukan peringkat dalam prestasi akademik juga menjadi suatu hal yang membanggakan dan diinginkan oleh banyak orangtua. Hal tersebut menyebabkan murid-murid terus berkompetisi agar menjadi lebih unggul secara akademik dengan teman-temanya. Begitu pula pada mahasiswa di perguruan tinggi, prestasi akademik seperti hasil Indeks Prestasi Kumulatif (IPK) sering dianggap menjadi patokan mahasiswa untuk menilai dirinya terkait keberhasilan dalam menjalani perkuliahan.

Menurut teori hirarki kebutuhan Abraham Maslow (Wormer, 2011) dinyatakan bahwa terdapat enam tahapan pemuasan kebutuhan manusia untuk mencapai aktualisasi diri. Enam tahapan tersebut antara lain kebutuhan fisiologis (physiological needs), kebutuhan akan keamanan (safety), kebutuhan untuk dimiliki dan cinta (belongingness and love), kebutuhan harga diri (self esteem), kebutuhan aktualisasi diri (self actualization), dan transendensi diri (self transcendence). Maslow juga menyatakan apabila tahapan sebelumnya belum terpenuhi, maka manusia tidak bisa mencapai tahapan berikutnya dengaan maksimal. Hal ini juga memengaruhi ketidakmampuan seseorang untuk mencapai tujuan kehidupan yaitu transendensi diri. Maslow (Feist \& Feist, 2010) menyatakan bahwa pada tahapan keempat yaitu kebutuhan akan harga diri meliputi mampu menghargai diri sendiri (self respect) dan juga mendapatkan penghargaan dari orang lain (respect from other). Salah satu hal yang dibutuhkan untuk memenuhi self respect seseorang yaitu adanya kebutuhan prestasi, penguasaan, kompetensi, kepercayaan diri, kemandirian, dan kebebasan. Respect from other yaitu kebutuhan akan prestise, penghargaan dari orang lain, status, ketenaran, dominasi, menjadi orang penting, kehormatan, diterima, dan diapresiasi. Orang-orang membutuhkan pengetahuan bahwa dirinya dikenal dengan baik dan dinilai dengan baik oleh orang lain. Apabila seseorang memiliki prestasi yang baik, maka individu tersebut akan mendapatkan pengakuan dan juga apresiasi dari orang lain atas keberhasilan prestasinya. Apabila individu telah mendapatkan indikator yang mampu mewakili pemuasan kebutuhan harga diri, maka individu bisa melanjutkan pada tujuan akhir yaitu kebutuhan transendensi diri.
Menurut Nurman (1994), prestasi belajar seseorang juga sangat memengaruhi masa depan seorang mahasiswa dan pilihan karirnya sehingga hal ini menyebabkan tingginya prestasi akademik dapat mempermudah jalan seseorang untuk mendapatkan pekerjaan yang layak. Besarnya pendapatan kerja sering dilihat dari riwayat prestasi akademik dan tinggi rendahnya pendidikan seseorang. Hal ini terlihat dari persyaratan-persyaratan umum yang biasanya ada pada informasi-informasi maupun iklan lowongan pekerjaan. Contohnya adalah terdapat persyaratan bahwa pelamar pekerjaan memiliki nilai IPK minimum yang telah ditentukan ataupun ada batasan lulusan pendidikan yang telah ditempuh. Pandangan orang-orang terhadap prestasi akademik menjadi salah satu pengukuran terhadap kualitas yang ada di dalam diri individu. Seseorang yang memiliki prestasi akademik baik cenderung mendapatkan perhatian positif dari lingkungannya.

Selain dituntut berprestasi secara akademik, mahasiswa juga hendaknya mengikuti kegiatan lain yang mampu membentuk pengalaman serta meningkatkan wawasan untuk bekal di masa depan. Maka dari itu, mahasiswa sebagai generasi penerus diharapkan tidak hanya kaya akan prestasi akademik seperti tingginya nilai IPK, tetapi diharapkan juga agar aktif dalam kegiatan-kegiatan lain yang berkontribusi mengasah soft-skill. Menurut Syawal (2010) agar mampu maksimal dan sukses menghadapi masa yang akan datang, generasi penerus bangsa diharapkan memiliki keseimbangan antara hard-skill dan soft-skill. Hard skill lebih beriorentasi kepada pengembangan intelligence quotient (IQ) sedangkan soft skill merupakan keterampilan seseorang dalam berhubungan dengan orang lain (interpersonal skills), memanajemen waktu, dan keterampilan mengatur dirinya sendiri (intrapersonal skills). Kegiatan yang dapat memfasilitasi kebutuhan-kebutuhan tersebut antara lain mengikuti organisasi mahasiswa seperti Badan Eksekutif Mahasiswa, Badan Perwakilan Mahasiswa, Himpunan Mahasiswa Jurusan, Komunitas Sosial, Pecinta Alam, Resimen Mahasiswa, pelatihan public speaking, sanggarsanggar penyaluran bakat, dan salah satu kegiatan yang sedang naik daun saat ini adalah mengikuti ajang Pageants.

Hasil studi awal yaitu wawancara dengan salah satu pemenang ajang Jegeg-Bagus Bali bernama Putu Ayu Saraswati yang dinobatkan sebagai Jegeg Bali tahun 2015 menyatakan bahwa ajang Pageants merupakan suatu ajang pemilihan duta-duta yang nantinya akan bertugas sebagai icon maupun perwakilan dalam suatu bidang yang telah ditentukan. Bidang-bidang dalam pemilihan duta ini pun sangat beragam dan berbeda-beda di setiap daerah. Kategori-kategori Pageants ada yang difokuskan untuk menjadi duta kecantikan maupun ketampanan, duta terkait pendidikan, pariwisata, budaya, teknologi, dan masih banyak lagi. Segala kategori-kategori pemilihan duta ini akhirnya dikelompokkan menjadi ajang yang disebut dengan ajang Pageants, sedangkan pemilihan 
yang dilaksanakan di daerah Bali disebut dengan Bali Pageants. Bali Pageants ini meliputi keseluruhan bentuk ajang Pageants yang dilaksanakan di Bali dari tingkat sekolah, perguruan tinggi, kota hingga provinsi yang diselenggarakan oleh pihak pemerintahan maupun pihak swasta. Contoh dari ajang Bali Pageants ini seperti: Jegeg-Bagus Bali, Terunateruni Denpasar, Duta Endek, Miss Internet, Puteri Indonesia Bali, Miss Indonesia Bali, Teruna-teruni Bali, Duta Bahasa, dan lain-lain (Puspita, 2016).

Puspita (2016) juga menyatakan, secara garis besar aspek-aspek yang dinilai agar dapat terpilih pada ajang tersebut antara lain penilaian dari aspek brain, beauty, dan behavior. Selain itu, untuk menjadi bagian dari finalis ajang ini dibutuhkan wawasan yang cukup luas tentang budaya, wawasan ipoleksusbudhankam (ilmu politik, ekonomi, sosial, budaya, pertahanan, dan keamanan), pengetahuan umum, bahasa daerah atau bahasa Bali, dan bahasa asing. Saraswati juga menyatakan bahwa terdapat 4 (empat) tahapan yang harus dilalui untuk lolos ke tahap finalis antara lain melewati tes interview, tes tulis, tes bakat, dan tes keterampilan.

Bali yang dikatakan sebagai Surga Dunia tentunya sering menjadi pusat perhatian dunia. Hasil wawancara dengan Putu Ayu Saraswati yang menjadi perwakilan dari Komunitas dan Organisasi Bali Pageants, menyatakan bahwa adanya kesan serta citra Bali yang positif inilah yang membuat banyak agensi-agensi, pihak pemerintah, maupun pihak swasta yang turut menyelenggarakan Peagent di pulau dewata (Bali Peagents). Sasaran dari ajang ini salah satunya adalah remaja dengan rentang usia rata-rata $17-24$ tahun. Tidak mengherankan jika banyak mahasiswa di Bali yang memanfaatkan kesempatan ini untuk mengikuti ajang Bali Pageants (Puspita, 2016). Salah satunya adalah mahasiswamahasiswi dari Fakultas Kedokteran Universitas Udayana. Fakultas Kedokteran Universitas Udayana juga memiliki citra yang baik di mata masyarakat Bali dari segi akademik maupun non-akademik serta memiliki banyak aktivitas non-akademik yang wajib dilakukan untuk memenuhi pelaksanaan Tri Dharma Perguruan Tinggi. Menurut aturan akademik Fakultas Kedokteran Universitas Udayana (2015), mahasiswa Fakultas Kedokteran Universitas Udayana diwajibkan untuk aktif menjadi anggota inti maupun pengurus organisasi serta aktif dalam kegiatan kepanitiaan untuk memenuhi syarat yudisium. Segala tuntutan non akademik dan tuntutan akademik ini tentunya membuat mahasiswa yang merangkap menjadi finalis Bali Pageants membutuhkan strategi-strategi tertentu untuk tetap mempertahankan prestasi akademik dengan baik.

Mengingat banyaknya kegiatan dan peran menjadi seorang duta, mahasiswa yang menjadi Finalis Bali Pageants tentunya mengalami kendala-kendala berkaitan dengan kegiatan akademik. Menurut hasil studi pendahuluan yaitu wawancara dengan dua finalis Bali Pageants menyatakan bahwa salah satu masalah yang paling sering terjadi adalah tertinggal materi perkuliahan. Hal ini karena finalis Bali Pageants dituntut untuk menjalankan tugasnya menjadi duta. Kedua finalis yang diwawancara juga menyampaikan jika absen di kelas atau bolos cukup sering mereka lakukan demi mampu memenuhi tugas yang diperintahkan. Finalis Bali Pageants menyatakan tidak diperbolehkan untuk menolak karena tugas tersebut sering berkaitan dengan tugas pemerintahan. Selain itu, finalis Bali Pageants juga sudah terikat kontrak selama satu tahun untuk aktif menjalankan tugas sebagai perwakilan duta masyarakat (Puspita, 2016). Hal ini menjadi sebuah masalah yang patut diperhatikan karena finalis Bali Pageants tentunya tidak dapat melupakan tugas utama sebagai mahasiswa yang menuntut ilmu. Keseimbangan antara prestasi akademik dan kegiatan ekstra tersebut idealnya akan menjadikan individu lebih siap untuk menghadapi kehidupannya di masa mendatang. Mahasiswa-mahasiswa yang aktif dalam kegiatan seperti ini memerlukan strategi khusus agar prestasi akademik seperti hasil IPK mereka tetap tinggi.

Hasil prestasi akademik dapat dipengaruhi oleh faktor-faktor yang menunjang proses dalam belajar salah satunya adalah bagaiamana seseorang menerapkan gaya belajarnya. Menurut De Porter dan Hernacki (2003), gaya belajar seseorang adalah kunci untuk mengembangkan kinerja dalam pekerjaan, disekolah, dan dalam situasi indvidu sehingga mampu mencapai prestasi belajar yang lebih baik. Adapun gaya belajar seseorang dibagi menjadi tiga jenis yaitu gaya belajar visual, auditorial, dan kinestetik. Selain ketiga tipe belajar tersebut, De Porter dan Hernacki (2003) juga mengatakan bahwa ada tipe campuran dari tiga gaya belajar seseorang, misalnya kombinasi gaya auditori-visual atau visual-kinestetik atau bisa ketiganya, namun tetap terdapat satu tipe belajar yang mendominasi. Selain memiliki gaya belajar masing-masing, individu juga membutuhkan kemampuan untuk mengorganisasikan dan mendisiplinkan kegiatan belajar agar mampu mengoptimalkan potensi dalam diri untuk meraih prestasi akademik yang optimal terlebih lagi ketika pelajar tersebut memiliki kegiatan ekstra lain seperti kegiatan Pageants yang membuat individu membutuhkan strategi untuk tetap berhasil pada kegiatan akademik.

Keberhasilan seseorang untuk bisa berprestasi di bangku perkuliahan dan kegiatan Pageants tentu sangat ditentukan oleh kemampuan mengaktualisasikan potensi diri secara optimal. Zimmerman (1998) menyatakan salah satu aspek mental yang sangat menentukan keberhasilan mengaktualisasikan potensi diri adalah self regulated learning (SRL). Zimmerman (1989) berpendapat bahwa siswa yang memiliki self regulated learning adalah siswa yang secara metakognitif, motivasional, dan behavioral merupakan peserta aktif dalam proses belajar. SRL membuat pelajar mampu mengobservasi dan mengevaluasi cara belajar mereka menjadi efektif, bisa memonitor diri, dan merancang strategi belajar 


\section{S. A. L. PUSPITA DAN I M. RUSTIKA}

mereka sendiri. Siswa yang belajar dengan regulasi diri bukan hanya tahu tentang apa yang dibutuhkan oleh setiap tugas, tetapi mereka juga dapat menerapkan strategi yang dibutuhkan. Strategi belajar mandiri yang cocok dengan karakteristik individu akan memengaruhi efektifitas proses belajar seseorang. Hasil penelitian Elianawani dan Wahyuni (2010) menunjukkan bahwa pemberian kebebasan memilih pola belajar sesuai dengan minat pelajar ternyata memberi kenyamanan belajar dan motivasi berkompetisi yang positif sehingga pencapaian belajar menjadi lebih baik. Mahasiswa dianggap cukup mampu mengobservasi dan mengevaluasi cara belajar mereka menjadi efektif, serta merancang strategi belajar sesuai situasi yang sedang dihadapi sehingga menghasilkan prestasi akademik yang baik. Self regulated learning pun dapat memaksimalkan potensi akademik dalam diri seseorang sehingga nantinya akan memengaruhi hasil dari prestasi akademik mereka di sekolah maupun perguruan tinggi.

Baik buruknya prestasi akademik yang dicapai juga tidak terlepas dari bagaimana individu tersebut mampu menilai dan memahami dirinya. Kemampuan menilai diri tersebut disebut dengan konsep diri. Konsep diri merupakan suatu aspek mental yang berkaitan dengan hampir seluruh aktivitas manusia salah satunya adalah prestasi (Hurlock, 1980). Slavin (2011a) menyatakan bahwa konsep diri adalah cara seseorang memahami kekuatan, kelemahan, kemampuan, sikap, dan nilai dalam dirinya. Hurlock (1980) juga menjelaskan bahwa konsep diri merupakan penilaian terhadap dirinya sendiri yang meliputi penilaian terhadap karakteristik fisik, psikis, sosial emosional, aspirasi, dan prestasi. Fitts (dalam Agustiani, 2009) juga menyatakan hal yang serupa bahwa konsep diri merupakan penilaian terhadap diri internal (identitas diri, diri sebagai pelaku, diri sebagai pengamat dan penilai) dan diri eksternal (diri fisik, diri etik-moral, diri personal, diri keluarga, diri sosial). Gabungan dari berbagai komponen internal maupun eksternal tersebutlah yang akhirnya membentuk konsep diri seseorang. Konsep diri juga diaanggap sebagai kemampuan seseorang untuk menjadi subjek dan objek sekaligus untuk melakukan penilaian tentang dirinya sendiri. Hal ini disebut dengan looking glass self (bercermin diri) yaitu mengimajinasikan suatu persepsi mengenai dirinya dalam pikiran orang lain (Cooley, 1902).

Konsep diri tidak semata-mata terbentuk karena pandangan subyektif diri sendiri, melainkan terbentuk dari pengalaman-pengalaman selama hidup dan bagaimana lingkungan menilai dirinya (Slavin, 2009). Konsep diri akan memengaruhi setiap aktivitas manusia termasuk aktivitas untuk berprestasi (Hurlock, 1980). Apabila lingkungan atau pihak-pihak pendidikan formal memberikan respon atau pandangan positif terhadap seseorang, maka individu cenderung termotivasi untuk mencapai prestasi. Sebaliknya, apabila lingkungan memberikan respon atau pandangan negatif dalam diri seseorang, maka orang tersebut akan berkembang dan membentuk konsep diri negatif sehingga mempengaruhi perilaku belajarnya untuk mencapai prestasi akademik.

Tidak bisa dipungkiri bahwa prestasi akademik yang dicapai masing-masing individu pada pendidikan formal seperti pada perguruan tinggi selalu ada yang lebih unggul dan lebih rendah. Tidak maksimalnya seseorang mencapai prestasi akademik tentunya didasari oleh faktor-faktor tertentu. Berdasarkan penjelasann yang telah dipaparkan, peneliti merasa perlu untuk meneliti lebih dalam terkait peran self regulated learning dan konsep diri terhadap prestasi akademik mahasiswa yang aktif di kegiatan non-formal yaitu ajang Bali Pageants.

\section{METODE PENELITIAN}

\section{Variabel dan Definisi Operasional}

Variabel tergantung dalam penelitian ini adalah prestasi akademik serta variabel bebas dalam penelitian ini adalah self regulated learning dan konsep diri. Definisi operasional dari masing-masing variabel penelitian adalah sebagai berikut:

\section{Prestasi Akademik}

Prestasi akademik merupakan taraf penguasaan materi kuliah yang dinyatakan dalam bentuk angka, yang merupakan nilai rata-rata dari nilai kognitif (pengetahuan), afektif (sikap), dan psikomotor (tingkah laku). Nilai rata-rata tersebut disebut juga Indeks Prestasi Kumulatif (IPK).

\section{Self Regulated Learning}

Self regulted learning adalah kemampuan seseorang untuk meregulasi dan mengendalikan dirinya sendiri dalam proses belajar serta menyusun strategi-strategi belajar efektif, dimana strategi tersebut melibatkan kognitif, motivasi, dan perilaku untuk mencapai prestasi belajar yang diharapkan. Taraf self regulated learning diukur menggunakan skala Self Regulated Learning (SRL). Semakin tinggi skor yang diperoleh, maka semakin tinggi taraf self regulated learning yang dimiliki subjek.

\section{Konsep Diri}

Konsep diri adalah kemampuan seseorang menilai dirinya sendiri seperti menilai kemampuan, kelebihan, serta kekurangan yang didapatkan dari pihak ekstern (orang tua, masyarakat, lingkungan, teman sebaya, dan lain-lain) sepanjang kehidupan manusia. Konsep diri yang akhirnya dimiliki oleh seseorang merupakan hasil dari pengalamanpengalaman positif dan negatif selama hidup serta gabungan dari hasil penilaian-penilaian orang lain terhadap diri seseorang. Taraf konsep diri diukur menggunakan skala Konsep Diri (KD). Semakin tinggi skor yang diperoleh, maka semakin tinggi taraf konsep diri yang dimiliki subjek. 


\section{PAGEANTS}

\section{Responden}

Populasi peneltian ini adalah remaja akhir yang pernah menjadi finalis ajang Bali Pageants dengan status sebagai mahasiswa di Fakultas Kedokteran Universitas Udayana yang berjumlah 61 orang. Karakteristik populasi dalam penelitian ini antara lain:

1. Subjek yang diambil berjenis kelamin perempuan dan lakilaki

2. Subjek merupakan remaja akhir yang berusia 19 sampai 22 tahun

3. Subjek berstatus mahasiswa di Fakultas Kedokteran Universitas Udayana.

4. Subjek pernah menjadi finalis maupun menjadi pemenang dalam ajang-ajang Bali Pageants (seperti: ajang Jegeg-Bagus Bali, Jegeg-Bagus di masing-masing provinsi, ajang TerunaTeruni, ajang Duta Endek, Duta Batik, Miss Internet, Putri Bali, dan sebagainya).

Teknik pengambilan sampel pada penelitian ini adalah sampling jenuh, yaitu semua populasi digunakan sebagai sampel penelitian dikarenakan jumlah sampel yang relatif kecil. Skala yang disebarkan pada proses pengambila data adalah sebanyak 61 skala, namun hanya 60 skala yang diisi lengkap dan dapat dianalisis.

\section{Tempat Penelitian}

Penelitian dilaksanakan pada bulan Oktober 2016. Penelitian dilaksanakan dengan cara bertemu secara langsung dengan subjek yang memenuhi kriteria di Fakultas Kedokteran Universitas Udayana dan di tempat pertemuan lain yang sudah disepakati sebelumnya oleh peneliti dan subjek.

\section{Alat Ukur}

Alat ukur penelitian ini menggunakan arsip prestasi akademik mahasiswa yaitu Indeks Prestasi Kumulatif (IPK), skala self regulated learning, dan skala konsep diri. Skor mentah dari IPK masing-masing subjek distandarisasi terlebih dahulu menjadi skor $\mathrm{T}$ karena subjek penelitian berasal dari program studi dan semester yang berbeda sehingga mengambil beban mata kuliah yang tidak sama. Skala self regulated learning yang digunakan merupakan modifikasi skala dari Wolters (2003) yang telah dikembangkan oleh Riana (2014), dan skala konsep diri disusun oleh peneliti berdasarkan dimensi-dimensi konsep diri menurut pendapat Fitts (dalam Agustiani, 2009).

Skala self regulated learning terdiri dari 29 item pernyataan dan skala konsep diri terdiri dari 30 item pernyataan. Skala ini terdiri dari pernyataan positif (favorable) dan pernyataan negatif (unfavorable) dengan empat pilihan jawaban yaitu Sangat Sesuai (SS), Sesuai (S), Tidak Sesuai (TS), dan Sangat Tidak Sesuai (STS).

Menurut Azwar (2010), suatu alat tes dinyatakan memiliki validitas yang baik jika alat tersebut mampu memberikan hasil ukur yang sesuai dengan maksud dilakukannya pengukuran. Pada penelitian ini, uji validitas konstruk dilakukan dengan melihat koefisien korelasi item total sebesar 0,30 dan apabila jumlah proporsi item tidak memenuhi setiap dimensi alat ukur, maka koefisien korelasi item total dapat diturunkan menjadi 0,25 (Azwar, 2014). Teknik pengukuran reliabilitas yang digunakan pada penelitian ini adalah Croncbach Alpha dimana konstruk atau variabel dapat dikatakan reliabel jika nilai Croncbach Alpha lebih besar dari 0,60 (Ghozali, 2005).

Penyebaran skala uji coba alat ukur dilaksanakan sebanyak dua kali yaitu pertama pada tanggal 12 sampai 19 September 2016 yang diberikan kepada mahasiswa remaja akhir Fakultas Kedokteran Universitas Udayana. Setelah pelaksanaan uji coba skala pertama, skala self regulated learning tidak memenuhi syarat uji validitas dan reliabilitas sehingga dibutuhkan uji coba skala kedua yang dilaksanakan pada tanggal 21 September 2016. Skala uji coba kedua diberikan kepada mahasiswa semester V (lima) program studi Ilmu Kesehatan Masyarakat dan semester VII (tujuh) program studi Fisioterapi Fakultas Kedokteran Universitas Udayana.

Hasil uji validitas skala self regulated learning menunjukkan nilai koefisien korelasi item total bergerak dari 0,291 - 0,607. Hasil uji reliabilitas skala self regulated learning menunjukkan koefisien Alpha sebesar 0,886 yang berarti bahwa skala ini mampu mencerminkan $88,60 \%$ variasi skor murni subjek, sehingga dapat disimpulkan bahwa skala self regulated learning layak digunakan sebagai alat ukur untuk mengukur taraf self regulated learning.

Hasil uji validitas skala konsep diri menunjukkan nilai koefisien korelasi item total bergerak dari 0,313 - 0,665. Hasil uji reliabilitas skala konsep diri menunjukkan koefisien Alpha sebesar 0,908 yang berarti bahwa skala ini mampu mencerminkan 90,80\% variasi skor murni subjek, sehingga dapat disimpulkan bahwa skala konsep diri layak digunakan sebagai alat ukur untuk mengukur taraf konsep diri.

\section{Teknik Analisis Data}

Uji hipotesis dilakukan apabila data peneletian telah melewati syarat uji asumsi yaitu uji normalitas, uji linearitas, dan uji multikolinearitas. Uji normalitas pada penelitian ini menggunakan uji Kolmogorov Smirnov, uji linearitas dilakukan dengan menggunakan uji Compare Means, dan uji multikolinearitas dilakukan dengan melihat nilai Variance Inflation Factor (VIF) dan nilai Tolerance. Setelah melakukan uji asumsi, data penelitian dianalisis dengan menggunakan metode analisis regresi berganda untuk menguji hipotesis mayor dan hipotesis minor. Analisis data dilakukan dengan menggunakan bantuan software SPSS release 20.0. 


\section{S. A. L. PUSPITA DAN I M. RUSTIKA}

\section{HASIL PENELITIAN}

\section{Karakteristik Subjek}

Berdasarkan data karakteristik subjek, diperoleh bahwa total subjek berjumlah 60 orang dengan jenis kelamin perempuan sebanyak 45 orang dan laki-laki sebanyak 15 orang. Mayoritas subjek penelitian adalah berusia 20 tahun yaitu sebanyak 23 orang. mayoritas subjek memiliki IPK antara 3,00 sampai 3,50 yaitu sebanyak 42 orang atau sebesar $70 \%$. Subjek penelitian berasal dari enam program studi di Fakultas Kedokteran Universitas Udayana dan mayoritas subjek berasal dari program studi Pendidikan Dokter yaitu sebanyak 36 orang atau sebesar $60 \%$.

\section{Deskripsi Data Penelitian}

Hasil deskripsi penelitian variabel self regulated learning, konsep diri, dan prestasi akademik dapat dilihat pada tabel 1 .

\begin{tabular}{ccccccccc}
\multicolumn{10}{c}{ Tabel 1 } \\
\multicolumn{10}{c}{ Deskripsi data penelitian } \\
\hline Variabel & N & $\begin{array}{c}\text { Mean } \\
\text { Teoritis }\end{array}$ & $\begin{array}{c}\text { Mean } \\
\text { Empiris }\end{array}$ & $\begin{array}{c}\text { Std } \\
\text { Deviasi } \\
\text { Teoritis }\end{array}$ & $\begin{array}{c}\text { Std } \\
\text { Deviasi } \\
\text { Empiris }\end{array}$ & $\begin{array}{c}\text { Sebaran } \\
\text { Teoritis }\end{array}$ & $\begin{array}{c}\text { Sebaran } \\
\text { Empiris }\end{array}$ & $\mathrm{t}$ \\
\hline SRL & 60 & 72,5 & 82,90 & 14,5 & 8,186 & $29-116$ & $56-103$ & $\begin{array}{c}9,841 \\
(\mathrm{p}=0,000)\end{array}$ \\
KD & 60 & 75 & 87,65 & 15 & 8,559 & $30-120$ & $62-110$ & $\begin{array}{c}11,449 \\
(\mathrm{p}=0,000)\end{array}$ \\
PA & 60 & 50,00 & 49,9988 & 10,00 & 10,00063 & $0-100$ & $-3,28-$ & $\begin{array}{c}-0,001 \\
(\mathrm{p}=0,999)\end{array}$ \\
\hline
\end{tabular}

Hasil deskripsi statistik pada tabel 1 menunjukkan bahwa variabel self regulated learning memiliki mean teoritis yang lebih besar dari mean empiris sehingga menghasilkan perbedaan sebesar 10,400 dengan nilai $t$ sebesar 9,841 $(\mathrm{p}=0,000)$. Mean empiris yang diperoleh lebih besar dari mean teoritis (mean empiris > mean teoritis) menghasilkan sebuah kesimpulan bahwa subjek memiliki taraf self regulated learning yang tinggi. Rentang skor subjek penelitian adalah antara 56 sampai dengan 103. Berdasarkan penyebaran frekuensi, 93,33\% subjek memiliki skor yang berada di atas mean teoritis.

Hasil deskripsi statistik pada tabel 1 menunjukkan bahwa variabel konsep diri memiliki mean teoritis yang lebih besar dari mean empiris sehingga menghasilkan perbedaan sebesar 12,650 dengan nilai t sebesar 11,449 ( $\mathrm{p}=0,000)$. Mean empiris yang diperoleh lebih besar dari mean teoritis (mean empiris > mean teoritis) menghasilkan sebuah kesimpulan bahwa subjek memiliki taraf konsep diri yang tinggi. Rentang skor subjek penelitian adalah antara 62 sampai dengan 110 . Berdasarkan penyebaran frekuensi, 91,67\% subjek memiliki skor yang berada di atas mean teoritis.

Hasil deskripsi statistik pada tabel 1 menunjukkan bahwa prestasi akademik menunjukkan bahwa prestasi akademik memiliki mean teoritis sebesar 50,00 dan mean empiris sebesar 49,9988 sehingga memiliki perbedaan sebesar $-0,00117$ dengan nilai $t$ sebesar $-0,001 \quad(p=0,999)$. Mean empiris yang diperoleh lebih kecil dari mean teoritis (mean empiris < mean teoritis) yang berarti tidak terdapat perbedaan yang signifikan antara besarnya IPK dari masing-masing subjek penelitian.

\section{Uji asumsi}

\begin{tabular}{ccc} 
Tabel 2 \\
Uji normalitas data penelitian \\
\hline Koriabel & Kolmogorov-smirnov & Asymp. Sig. (2-tailed) (P) \\
\hline Self Regulated Learning & 0,543 & 0,930 \\
Konsep Diri & 0,669 & 0,762 \\
Prestasi Akademik (IPK) & 1,186 & 0,120 \\
\hline Total & 60 & $100 \%$ \\
\hline Uji normalitas & dilakukan & dengan analisis
\end{tabular}

Kolmogorov Smirnov dimana suatu sebaran data dapat dikatakan normal jika hasil p>0.05 (Santoso, 2003). Tabel 2 menunjukkan bahwa data variabel self regulated learning berdistribusi normal dengan nilai Kolmogorov Smirnov sebesar 0,543 dengan signifikansi 0,930 ( $p>0,05)$. Data pada variabel konsep diri berdistribusi normal dengan nilai Kolmogorov Smirnov sebesar 0,669 dengan signifikansi 0,762 ( $>00,05)$. Serta data prestasi akademik yaitu nilai IPK beridistribusi normal dengan nilai Kolmogorov-smirnov sebesar 1,186 dengan signifikansi 0,120 ( $p>0,05)$.

Tabel 3

Uji linearitas data penelitian

\begin{tabular}{|c|c|c|c|c|}
\hline & & & F & Signifikansi \\
\hline \multirow{3}{*}{$\begin{array}{l}\text { Prestasi Akademik*Self } \\
\text { Regulated Learning }\end{array}$} & Between Groups & Combined & 2,363 & 0,10 \\
\hline & & Linearity & 14.117 & 0.001 \\
\hline & & $\begin{array}{l}\text { Deviation from } \\
\text { linearity }\end{array}$ & 1,911 & 0,041 \\
\hline \multirow{3}{*}{$\begin{array}{c}\text { Prestasi } \\
\text { Akademik*Konsep Diri }\end{array}$} & Between Groups & Combined & 3,675 & 0,000 \\
\hline & & Linearity & 6.198 & 0.018 \\
\hline & & Deviation from & 3,578 & 0,000 \\
\hline
\end{tabular}

Uji linieritas dilakukan untuk mengetahui apakah hubungan antara variabel bebas dan variabel tergantung menunjukkan garis sejajar atau tidak (Sugiyono, 2014). Langkah kerja untuk melakukan uji linieritas adalah dengan melihat compare mean lalu menggunakan test of linearity. Hubungan dua variabel dikatakan signifikan linier jika $\mathrm{p}<0.05$. Tabel 3 menunjukkan hubungan yang linear antara prestasi akademik dan self regulated learning dengan nilai signifikansi $0,001(\mathrm{p}<0,05)$. Hubungan yang linear juga ditunjukkan antara prestasi akademik dan konsep diri dengan nilai signifikansi $0,018$ ( $\mathrm{p}<0,05)$. Maka dari itu dapat disimpulkan bahwa terdapat hubungan linear antara prestasi akademik dengan self regulated learning serta prestasi akademik dengan konsep diri.

\begin{tabular}{cccc}
\multicolumn{4}{c}{ Tabel 4 } \\
& Uji multikolinearitas data penelitian & \\
\hline Variabel & Tolerance & $\begin{array}{c}\text { Variance Inflation } \\
\text { Factor (VIF) }\end{array}$ & Keterangan \\
\hline $\begin{array}{c}\text { Self Regulated } \\
\text { Learning } \\
\text { Konsep Diri }\end{array}$ & 0,614 & 1,628 & Tidak ada multikolinearitas \\
& 0,614 & 1,628 & Tidak ada multikolinearitas
\end{tabular}

a. Dependent Variabel: Prestasi Akademik

Uji multikolineritas digunakan untuk mengetahui apakah terdapat korelasi antara variabel bebas satu dengan variabel bebas lainnya. Model regresi dianggap baik ketika variabel bebas tidak memiliki korelasi yang tinggi dengan variabel bebas lainnya. Hal tersebut dapat dilihat dari nilai VIF kurang dari $10(<10)$ dan nilai Tolerance yang lebih besar dari $0,1(>0,1)$ (Ghozali, 2005). Tabel 4 menunjukkan nilai 


\section{PERAN SELF REGULATED LEARNING DAN KONSEP DIRI TERHADAP PRESTASI AKADEMIK MAHASISWA REMAJA AKHIR FAKULTAS KEDOKTERAN UNIVERSITAS UDAYANA YANG PERNAH MENJADI FINALIS BALI PAGEANTS}

Tolerance sebesar $0,614(>0,1)$ dan nilai VIF sebesar 1,628 $(<10)$, sehingga dapat disimpulkan tidak terdapat multikolinearitas antar variabel bebas yang diteliti yaitu pada variabel self regulated learning dan konsep diri.

Berdasarkan uji normalitas, uji multikolinearitas, dan uji linearitas yang telah dilakukan maka dapat dikatakan data dalam penelitian ini berdistribusi normal, tidak ada multikolinearitas, dan menunjukkan hubungan yang linear sehingga dapat dilanjutkan ke tahap berikutnya yaitu analisis regresi berganda.

\section{Uji Hipotesis}

Hasil uji regresi berganda variabel self regulated learning dan konsep diri terhadap prestasi akademik adalah sebagai berikut:

\begin{tabular}{cccc}
\multicolumn{4}{c}{ Tabel 5 } \\
& Hasil uji regresi berganda data penelitian \\
\hline $\mathrm{R}$ & $\mathrm{R}$ Square & Adjusted R Square & Std. Error of the Estimate \\
\hline 0,385 & 0,148 & 0,118 & 9,39111 \\
\hline
\end{tabular}

Pengujian hipotesis mengenai parameter populasi menggunakan informasi dari sampel dan teori probabilitas untuk menentukan apakah hipotesis yang dibuat secara statistik mampu diterima atau ditolak. Hipotesis merupakan suatu jawaban yang bersifat sementara mengenai permasalahan penelitian yang dinyatakan dalam bentuk kalimat pertanyaan (Sugiyono, 2013). Pada penelitian ini, uji hipotesis menggunakan metode analisis regresi berganda dengan bantuan software SPSS release 20.0. Tabel 5 menunjukkan bahwa koefisien regresi (R) sebesar 0,385 dengan koefisien determinasi ( $\mathrm{R}$ Square) sebesar 0,148, yang berarti bahwa self regulated learning dan konsep diri secara bersama-sama berperan terhadap prestasi akademik dengan sumbangan efektif sebesar 14,8\%, sedangkan 85,2\% dipengaruhi oleh faktor ain yang tidak diteliti.

Tabel 6

\begin{tabular}{cccccc}
\multicolumn{7}{c}{ Tabel 6 } \\
\multicolumn{7}{c}{ Hasil uji regresi berganda signifikansi F } \\
\hline & Sum of Squares & df & Mean Square & F & Sig \\
\hline Regression & 873,745 & 2 & 436,873 & 4,954 & $0,010^{\mathrm{b}}$ \\
Residual & 5027,002 & 57 & 88,193 & & \\
\hline Total & 5900,747 & 59 & & & \\
\hline
\end{tabular}

Tabel 6 menunjukkan bahwa $F$ hitung adalah sebesar 4,954 dengan taraf signifikansi $0,010(<0,05)$ sehingga model regresi dapat digunakan untuk memprediksi prestasi akademik. Berdasarkan hasil di atas, dapat disimpulkan bahwa self regulated learning dan konsep diri secara bersama-sama berperan terhadap prestasi akademik.

Tabel 7

Hasil Uji Regresi Berganda Nilai Koefisien Beta dan Nilai T Variabel Self Regulated Learning Hasil Uji Regresi Berganda Nilai Koefisien Beta dan Nilai T Variabel Self Regulated Learning
dan Konsep Diri Terhadap Prestasi Akademik

\begin{tabular}{|c|c|c|c|c|c|}
\hline \multirow[b]{2}{*}{ Model } & \multicolumn{2}{|c|}{ Unstandarized Coefficients } & \multirow{2}{*}{$\begin{array}{c}\begin{array}{c}\text { Standarized } \\
\text { Coefficient }\end{array} \\
\text { Beta } \\
\end{array}$} & \multirow[b]{2}{*}{$\mathrm{t}$} & \multirow[b]{2}{*}{$\mathrm{Sig}$} \\
\hline & B & Std. Error & & & \\
\hline (Constant) & 12,475 & 13,885 & & 0,898 & 0,373 \\
\hline $\begin{array}{l}\text { Self Regulated } \\
\text { Learning }\end{array}$ & 0,495 & 0,191 & 0,405 & 2,597 & 0,012 \\
\hline Konsep Diri & $-0,040$ & 0,182 & $-0,034$ & $-0,220$ & 0,827 \\
\hline
\end{tabular}

Tabel 7 menunjukkan bahwa variabel self regulated learning memiliki koefisien beta terstandarisasi 0,405 dengan nilai t sebesar 2,597 serta taraf signifikansi 0,012 ( $<<0,05)$ yang berarti self regulated learning berpengaruh secara signifikan terhadap prestasi akademik. Variabel bebas lainnya yaitu konsep diri memiliki koefisien beta $-0,034$ dengan nilai $t$ $-0,220$ serta taraf signifikansi $0,827(p>0,05)$ yang berarti konsep diri tidak berpengaruh terhadap prestasi akademik. Berdasarkan hasil di atas, dapat disimpulkan bahwa variabel self regulated learning mempunyai pengaruh yang lebih besar terhadap prestasi akademik dibandingkan variabel konsep diri.

Hasil uji regresi berganda pada tabel 20 juga dapat memprediksi taraf prestasi akademik masing-masing subjek dengan melihat persamaan garis regresi sebagai berikut:

$$
\begin{aligned}
& \text { Keterangan: } \\
& Y=\text { Prestasi Akademik } \\
& X 1=\text { Self Regulated Learning } \\
& X 2=\text { Konsep Diri }
\end{aligned}
$$$$
\mathrm{Y}=12,475+(0,495)(\mathrm{X} 1)+(-0,040)(\mathrm{X} 2)
$$

a. Konstanta sebesar 12,475 menyatakan bahwa jika tidak ada penambahan atau pengurangan skor pada self regulated learning dan konsep diri maka taraf prestasi akademik adalah sebesar 12,475.

b. Koefisien regresi X1 sebesar 0,495 menyatakan bahwa setiap penambahan atau peningkatan satuan skor subjek pada variabel self regulated learning maka akan terjadi kenaikan taraf prestasi akademik sebesar 0,495.

c. Koefisien regresi sebesar $(-0,040)$ menyatakan bahwa pada setiap penambahan atau peningkatan satuan skor subjek pada variabel konsep diri akan mengurangi taraf prestasi akademik sebesar 0,040.

Rangkuman hasil uji hipotesis mayor dan hipotesis minor dalam penelitian ini dapat dilihat pada rangkuman tabel 8.

\begin{tabular}{clc}
\multicolumn{4}{c}{ Tabel 8 } \\
\multicolumn{1}{c}{ Rangkuman hasil uji hipotesis penelitian } \\
\hline No & \multicolumn{1}{c}{ Hipotesis } & Hasil \\
\hline 1 & $\begin{array}{l}\text { Hipotesis Mayor: } \\
\text { Self regulated learning dan konsep diri berperan terhadap prestasi } \\
\text { akademik mahasiswa remaja akhir yang pernah menjadi finalis ajang } \\
\text { Bali Pageants }\end{array}$ & Diterima \\
2 & $\begin{array}{l}\text { Hipotesis Minor: } \\
\text { a. } \quad \begin{array}{l}\text { Self regulated learning berperan terhadap prestasi akademik } \\
\text { mahasiswa remaja akhir yang pernah menjadi finalis ajang Bali }\end{array}\end{array}$ & Diterima \\
& $\begin{array}{l}\text { Pageants } \\
\text { b. } \begin{array}{l}\text { Konsep diri berperan terhadap prestasi akademik mahasiswa remaja } \\
\text { akhir yang pernah menjadi finalis ajang Bali Pageants }\end{array}\end{array}$ & Ditolak \\
\hline
\end{tabular}

\section{PEMBAHASAN DAN KESIMPULAN}

Berdasarkan hasil penelitian yang telah dipaparkan, hasil analisis dengan menggunakan teknik regresi berganda menunjukkan bahwa pengujian hipotesis mayor adanya peran self regulated learning dan konsep diri pada mahasiswa remaja akhir Fakultas Kedokteran Universitas Udayana yang pernah menjadi finalis Bali Pageants dapat diterima. Hal ini dapat dilihat dari hasil nilai koefisien $\mathrm{R}$ sebesar 0,385 serta nilai $\mathrm{F}$ hitung sebesar 4,954 dengan taraf signifikansi 0,010 ( $p<0,05)$. Selain itu, terdapat koefisien determinasi yang menunjukkan 


\section{S. A. L. PUSPITA DAN I M. RUSTIKA}

nilai sebesar 0,148 yang menunjukkan bahwa variabel self regulated dan konsep diri memberi sumbangan efektif sebesar $14,8 \%$ terhadap prestasi akademik mahasiswa remaja akhir Fakultas Kedokteran Universitas Udayana yang pernah menjadi finalis Bali Pageants, sedangkan sisanya sebesar $85,2 \%$ dipengaruhi oleh variabel lain yang tidak diteliti.

Hasil koefisien beta terstandarisasi menunjukkan bahwa variabel self regulated learning memiliki beta terstandarisasi sebesar 0,405 dengan nilai t 2,597 dan taraf signifikansi sebesar 0,012 ( $<<0,05)$ sehingga dapat disebutkan bahwa self regulated learning berperan terhadap prestasi akademik. Self regulated learning merupakan suatu strategi seseorang untuk mampu meregulasi diri dalam aktivitas belajar dengan tujuan menghasilkan prestasi akademik yang memuaskan. Self regulated learning membuat pelajar mampu mengobservasi dan mengevaluasi cara belajar mereka menjadi efektif, bisa memonitor diri, disiplin, mandiri dan merancang strategi belajar mereka sendiri (Zimmerman, dkk., 1996). Mahasiswa yang menerapkan Self regulated learning akan mampu mengulang materi pelajaran yang didapatkan di perkuliahan secara rutin, merancang jadwal belajar yang diikuti secara konsisten, memiliki usaha untuk mempelajari materi lebih dalam dengan menanyakan kepada orang lain yang dianggap mampu, membagi waktu secara efektif untuk bisa menyelesaikan tugas tepat waktu, menyusun goals atau target pencapaian, serta mengevaluasi hasil prestasi akademik.

Mahasiswa Fakultas Kedokteran Universitas Udayana memiliki tuntutan akademik yang cukup tinggi sehingga membutuhkan kemampuan self regulated learning untuk bisa mempertahankan prestasi akademiknya. Terlebih lagi apabila mahasiswa tersebut juga memiliki banyak aktivitas lain untuk meningkatkan kemampuan soft-skill salah satunya menjadi duta dalam kegiatan ajang Bali Pageants. Selain menyadari gaya belajar yang sesuai dengan keadaan individu seperti gaya belajar visual, auditorial, dan kinestetik untuk menunjang prestasi belajar, kemampuan meregulasi diri dalam belajar juga tidak kalah penting untuk diterapkan agar mahasiswa mampu mengatur diri dan menentukan strategi belajar yang cocok dengan situasi yang dihadapi sehingga mampu menghasilkan prestasi akademik yang lebih optimal. Hasil penelitian Elianawani dan Wahyuni (2010) menunjukkan bahwa pemberian kebebasan memilih pola belajar sesuai dengan minat pelajar ternyata memberi kenyamanan belajar dan motivasi berkompetisi yang positif sehingga pencapaian belajar menjadi lebih baik. Mahasiswa dianggap cukup mampu mengobservasi dan mengevaluasi cara belajar mereka menjadi efektif, serta merancang strategi belajar sesuai situasi yang sedang dihadapi sehingga menghasilkan prestasi akademik yang baik.
Disiplin pada jadwal belajar dapat membuat mahasiswa menggunakan waktu secara efektif sehingga tetap bisa membagi waktu untuk kegiatan ekstra lainnya. Individu dengan regulasi yang baik juga mampu mengatur materi yang dipelajari agar dapat meningkatkan efektivitas proses pembelajaran dan mengubah materi pelajaran menjadi lebih sederhana dan mudah dipelajari. Mahasiswa dengan self regulatd learning juga memiliki kemampuan untuk mengevaluasi diri dalam belajar seperti tidak mengulang strategi belajar yang salah atau mengevaluasi kekurangankekurangan dari hasil pencapaian prestasi akademik. Begitu pula sebaliknya, individu yang memiliki self regulated learning rendah cenderung mengalami kesulitan untuk mengatur jadwal dan strategi belajar yang efektif, sehingga prestasi akademik yang diraihpun tidak optimal.

Variabel konsep diri memiliki nilai koefisien beta terstandarisasi $-0,034$ dengan nilai $t \quad-0,220$ dan taraf signifikansi yaitu 0,827 ( $p>0,05)$ yang berarti bahwa konsep diri tidak berpengaruh secara signifikan terhadap prestasi akademik. Konsep diri merupakan kemampuan seseorang menilai dirinya sendiri seperti menilai kemampuan, kelebihan, serta kekurangan yang didapatkan dari pihak eksternal (orang tua, masyarakat, lingkungan, teman sebaya, dan lain-lain) sepanjang kehidupan manusia (Slavin, 2009a). Menurut Hurlock (1980) memasuki usia remaja, inidividu mengalami perubahan emosi, tubuh, minat, peran, pola perilaku, perubahan pada nilai-nilai yang dianut, dan menginginkan kebebasan. Apabila remaja terlalu fokus dengan salah satu minat dan perannya menjadi seorang duta atau figur masyarakat, remaja dapat memiliki kecenderungan untuk mengesampingkan kewajiban utamanya yaitu sebagai mahasiswa. Walaupun mahasiswa tersebut memiliki konsep diri yang positif namun minat terhadap kegiatan akademiknya rendah, maka mahasiswa remaja akhir yang pernah menjadi finalis Bali Pageants tersebut tidak akan terpacu untuk mencapai prestasi akademik yang optimal. Hasil ini sejalan dengan hasil uji analisis teknik regresi berganda dari Chairiyati (2013) yang menyatakan bahwa konsep diri tidak berperan secara signifikan terhadap prestasi akademik mahasiswa Fakultas dan Jurusan Psikologi Universitas Swasta di Jakarta. Hasil penelitian ini dapat menguatkan bahwa konsep diri yang dimiliki seorang mahasiswa tidak berperan terhadap pencapaian prestasi akademik di perkuliahan. Begitu pula para finalis Bali Pageants yang merupakan seorang mahasiswa, konsep diri yang terbentuk dari penilaian subyektif maupun penilaian pihak eksternal tidak berperan secara signifikan dengan prestasi akademik yang dicapai.

Remaja juga akan mempersiapkan diri untuk mencapai karir, jabatan, dan profesi tertentu (Syah, 2014). Menjadi seorang finalis Bali Pageants dapat dikatakan sebagai cerminan pilihan karir dari seorang remaja. Cerminan pilihan 


\section{PERAN SELF REGULATED LEARNING DAN KONSEP DIRI TERHADAP PRESTASI AKADEMIK MAHASISWA REMAJA AKHIR FAKULTAS KEDOKTERAN UNIVERSITAS UDAYANA YANG PERNAH MENJADI FINALIS BALI PAGEANTS}

karir tersebut dapat berupa menjadi figur masyarakat, tokoh sosial maupun politik, tokoh-tokoh pemerhati budaya, dan sejenisnya. Remaja yang menjadi Bali Pageants akan menilai dirinya membanggakan dan dapat dikatakan sukses karena mampu menjadi figur masyarakat yang berpenghasilan dalam usia muda. Apabila tidak diedukasi dengan tepat, remaja akan merasa cukup dengan pencapaiannya saat ini dan merasa bahwa kesuksesan tidak harus berasal dari pencapaian prestasi yang baik di bidang akademik. Hal ini membuat individu tidak termotivasi untuk melakukan upaya-upaya belajar untuk mencapai indeks prestasi yang memuaskan.

Berdasarkan deskripsi data penelitian variabel self regulated learning, didapatkan bahwa mahasiswa remaja akhir Fakultas Kedokteran Universitas Udayana yang pernah menjadi finalis ajang Bali Pageants memiliki self regulated learning yang tinggi. Hal ini berkaitan dengan aktivitas akademik yang ketat dan padat. Mahasiswa dituntut untuk bisa menghadapi banyaknya tugas akademik dalam bentuk individu maupun kelompok yang disertai dengan tugas-tugas non-akademik lain. Seluruh mahasiswa di Fakultas Kedokteran Universitas Udayana diwajibkan untuk aktif pada kegiatan organisasi dan kemahasiswaan karena menjadi salah satu syarat untuk mengikuti yudisium. Kewajiban ini menjadi tanggung jawab yang cukup besar karena mahasiswa membutuhkan banyak waktu dan tenaga agar kewajiban tersebut dapat terlaksana dengan baik. Hal ini membuat mahasiswa Fakultas Kedokteran Universitas Udayana dituntut untuk mampu membuat prioritas tugas, melakukan evaluasi, membagi waktu belajar, serta mengatur jadwal belajar yang tepat agar tetap mencapai prestasi akademik yang diharapkan.

Fakultas Kedokteran Universitas Udayana memiliki sistem kurikulum yang terdiri dari, pemaparan materi atau lecture, diskusi kelompok atau yang biasa disebut small group discussion (SGD), dan juga presentasi hasil diskusi yang disebut pleno. Mahasiswa dibiasakan untuk melaksanakan setiap tahapan proses belajar agar selesai tepat waktu dengan hasil yang maksimal. Maka dari itu, secara tidak langsung Fakultas Kedokteran Universitas Udayana juga menerapkan self regulated learning melalui proses belajar mengajarnya, sehingga mahasiswa terbiasa dengan jadwal dan sistem belajar yang konsisten.

Hasil deskriptif penelitian menunjukkan bahwa mayoritas mahasiswa remaja akhir Fakultas Kedokteran Universitas Udayana yang pernah menjadi finalis ajang Bali Pageants memiliki konsep diri tinggi. Seseorang yang pernah menjadi finalis ajang Bali Pageants memiliki tugas untuk menjadi salah satu perwakilan duta dalam bidang-bidang tertentu seperti bidang pariwisata, pendidikan, kecantikan, dan lain-lain. Agar dapat terpilih menjadi seorang finalis, mereka wajib melewati beberapa seleksi dari segi brain, beauty, dan behavior. Finalis-finalis tersebut tentunya sudah terbiasa dihadapkan dengan situasi-situasi yang menuntut mereka untuk berhadapan di depan umum. Selain itu, mereka diakui telah memiliki poin ekstra dalam kemampuan brain, beauty, dan behavior dibandingkan remaja lainnya. Adanya kesankesan positif yang tercipta dari masyarakat tentang kemampuan finalis kemudian membentuk konsep diri positif sehingga mereka merasa percaya diri dan merasa berkompeten.

Nilai koefisien beta terstandarisasi variabel self regulated learning lebih besar dari pada koefisien beta terstandariasasi variabel konsep diri. Hal tersebut menunjukkan bahwa self regulated learning lebih berperan terhadap prestasi akademik dibandingkan konsep diri. Mahasiswa yang menerapkan regulasi diri dalam belajar memiliki kemampuan mengevaluasi diri yang baik. Hal ini membuat mahasiswa dapat meningkatkan performa belajar mereka dengan cara memperbaiki diri dan tidak mengulangi kesalahan yang sama. Mahasiswa dengan self regulated learning juga dapat mengatur dan merancang tujuan dengan tepat. Perencanaan tujuan belajar akan membantu siswa untuk menemukan permasalahan yang menghambat sehingga dapat meminimalisir kessalahan pengerjaan tugas. Melakukan perencanaan juga membuat individu dapat memprioritaskan hal-hal yang penting bagi perolehan kesuksesan jangka panjang, seperti mengerjakan tugas-tugas akademik terlebih dahulu kemudian menyelesaikan tugasnya sebagai finalis Bali Pageants. Selain itu, mereka akan menggunakan strategi belajar seperti mempraktekkan teori yang sudah dipelajari untuk mendapatkan pemahaman yang lebih dalam. Menurut Syah (2014) individu yang lebih sering mempraktikkan materi pelajaran akan mampu mengingat teori tersebut lebih lama.

Remaja dengan self regulated learning yang baik akan memiliki motivasi tersendiri untuk dapat mencapai prestasi yang diharapkan. Mereka memiliki inisiatif yang tinggi untuk menggali informasi terkait pelajaran dengan cara aktif bertanya pada teman sebaya, guru, dan orang dewasa lainnya sehingga dapat memperluas wawasan mereka. Mereka memiliki motif ekstrinsik yang disebut "ego-enhancement" yaitu ambisi pribadi untuk meningkatkan prestasi dirinya dengan cara meraih indeks prestasi setinggi-tingginya (Syah, 2014). Motivasi yang mereka miliki dapat memicu mereka untuk terus mengembangkan keterampilan belajar yang cerdik dan efesien. Seorang mahasiswa dengan self regulated learning memiliki kolaborasi antara kognitif, afektif, dan motivasional untuk meraih pencapaian akademik yang diharapkan. 


\section{S. A. L. PUSPITA DAN I M. RUSTIKA}

Prestasi akademik merupakan taraf penguasaan materi kuliah yang dinyatakan dalam bentuk angka, yang diperoleh dari rata-rata nilai kognitif, afektif, dan psikomotor sehingga penting adanya kedisiplinan belajar maupun tingkat inteligensi yang dapat mendukung pencapaian prestasi akademik yang optimal. Apabila mahasiswa hanya terpaku dengan konsep diri yang mereka miliki, seperti memiliki rasa percaya diri dan penghargaan diri namun tidak diimbangi dengan pengelolaan diri agar dapat menguasai materi perkuliahan, maka mahasiswa tersebut cenderung tidak mampu meraih hasil prestasi akademik yang maksimal. Terlebih lagi finalis Bali Pageants masih tergolong mahasiswa aktif di Fakultas Kedokteran Universitas Udayana yang memiliki tuntutan akademik yang ketat, sehingga untuk mencapai prestasi akademik yang maksimal, mahasiswa lebih membutuhkan kedisiplinan diri dalam belajar untuk meraih nilai-nilai ujian yang memuaskan. Hal itulah yang menyebabkan, kemampuan meregulasi diri dalam belajar berkontribusi lebih besar terhadap pencapaian prestasi akademik dibandingkan dengan konsep diri.

Adapun keterbatasan dalam penelitian ini adalah keterbatasan jumlah subjek yang memenuhi kriteria subjek penelitian. Subjek penelitian yang didapatkan di Fakultas Kedokteran Universitas Udayana berjumlah 60 orang dan digunakan seluruhnya. Walaupun dalam teknik pengambilan sampel jenuh subjek berjumlah 30 orang dikatakan sudah cukup banyak (Sugiyono, 2014). Dikarenakan jumlah subjek yang memenuhi kriteria sangat terbatas, peneliti tidak dapat memberikan skala try out kepada subjek dengan kriteria yang sama persis. Namun peneliti telah memberikan skala try out untuk diisi oleh subjek dengan karakteristik yang serupa yaitu subjek yang tergolong sebagai mahasiswa dan sedang dalam masa remaja akhir. Keterbatasan lainnya yang ditemui peneliti adalah dalam pelaksanaan terkait skala self regulated learning yaitu ketika melaksanakan uji coba skala. Setelah melakukan uji validitas dan reliabilitas ditemukan bahwa item dari skala self regulated learning mengalami keguguran item sehingga terdapat beberapa dimensi yang tidak terwakili oleh item. Peneliti memperkirakan bahwa banyaknya item yang gugur dapat disebabkan oleh ketidak seriusan subjek saat mengerjakan kuisioner serta terbatasnya waktu pengisian karena subjek harus mengikuti perkuliahan selanjutnya. Selain itu, banyaknya item yang gugur juga bisa disebabkan karena terdapat beberapa item yang pernyataannya rumit dan kurang komprehensif. Hal ini menyebabkan peneliti membutuhkan uji coba skala self regulated learning untuk kedua kalinya.

Setelah melakukan prosedur analisis data penelitian, karya ini telah mencapai tujuan penelitian yaitu mengetahui peran self regulated learning dan konsep diri terhadap prestasi akademik mahasiswa remaja akhir Fakultas Kedokteran Universitas Udayana yang pernah menjadi finalis ajang Bali
Pageants, mengetahui peran self regulated learning terhadap prestasi akademik mahasiswa remaja akhir Fakultas Kedokteran Universitas Udayana yang pernah menjadi finalis ajang Bali Pageants, dan mengetahui peran konsep diri terhadap prestasi akademik mahasiswa remaja akhir Fakultas Kedokteran Universitas Udayana yang pernah menjadi finalis ajang Bali Pageants.

Berdasarkan penelitian yang telah dilakukan, dapat ditarik kesimpulan bahwa self regulated learning dan konsep diri secara bersama-sama berperan terhadap prestasi akademik mahasiswa remaja akhir Fakultas Kedokteran Universitas Udayana yang pernah menjadi finalis ajang Bali Pageants, self regulated learning berperan terhadap prestasi akademik mahasiswa remaja akhir Fakultas Kedokteran Universitas Udayana yang pernah menjadi finalis ajang Bali Pageants, konsep diri tidak berperan secara signifikan terhadap prestasi akademik mahasiswa remaja akhir Fakultas Kedokteran Universitas Udayana yang pernah menjadi finalis ajang Bali Pageants, self regulated learning mahasiswa remaja akhir Fakultas Kedokteran Universitas Udayana yang pernah menjadi finalis Bali Pageants tergolong tinggi, konsep diri mahasiswa remaja akhir Fakultas Kedokteran Universitas Udayana yang pernah menjadi finalis Bali Pageants tergolong tinggi, prestasi akademik mahasiswa remaja akhir Fakultas Kedokteran Universitas Udayana yang pernah menjadi finalis Bali Pageants tergolong sedang.

Berdasarkan kesimpulan yang telah dipaparkan, maka peneliti memberikan saran kepada orang tua agar mampu mengarahkan anak yang berperan sebagai mahasiswa dan juga finalis Bali Pageants untuk tetap menerapkan self regulated learning sehingga dapat menjalankan tugas utama sebagai mahasiswa dengan baik. Pengarahan yang diberikan dapat berupa edukasi mengenai contoh-contoh penerapan self regulated learning yang baik, orang tua mampu mengarahkan dan memberi kesempatan kepada anak untuk belajar mandiri, belajar mengevaluasi hasil prestasi akademik, dan membuat suasana rumah menjadi tempat belajar yang kondusif. Hal ini diharapkan membuat anak menjadi lebih termotivasi untuk meningkatkan kemampuan self regulated learning ketika berada di rumah, serta orangtua diharapkan mampu mengingatkan anak untuk tidak hanya fokus pada kegiatan non-akademik atau hobby-nya, melainkan tetap mengingat tugas utama mereka sebagai mahasiswa yaitu belajar dengan memberikan informasi dan pengertian tentang pentingnya pencapaian prestasi akademik serta pentingnya keseimbangan soft-skill dan hard-skill untuk menghasilkan keberhasilan yang optimal.

Saran bagi remaja akhir yang pernah menjadi finalis Bali Pageants yaitu diharapkan dapat mempertahankan dan meningkatkan kemampuan meregulasi diri dalam belajar 


\section{PERAN SELF REGULATED LEARNING DAN KONSEP DIRI TERHADAP PRESTASI AKADEMIK MAHASISWA REMAJA AKHIR FAKULTAS KEDOKTERAN UNIVERSITAS UDAYANA YANG PERNAH MENJADI FINALIS BALI PAGEANTS}

sehingga tetap mampu meraih prestasi akademik yang optimal. Hal ini dapat dilakukan dengan cara menerapkan strategi self regulated learning seperti seeking from the others yaitu bertanya kepada pihak lain yang dianggap mampu memberikan informasi mengenai materi perkuliahan yang mungkin sempat terlewatkan karena menjalankan tugas sebagai finalis Bali Pageants. Kemampuan self regulated learning juga perlu disadari oleh mahasiswa remaja akhir yang memiliki kegiatan ekstra seperti menjadi Finalis Bali Pageants agar tetap menyeimbangkan pencapaian prestasi akademik dan prestasi non-akademik. Kesadaran ini dapat dimunculkan dengan mendalami dan mencari informasi terkait penerapan self regulated learning melalui media-media informasi maupun hasil penelitian serta kepada mahasiswa lain yang sudah memiliki prestasi akademik baik meskipun memiliki berbagai kegiatan ekstra.

Saran bagi lembaga pendidikan formal yaitu pihak Fakultas dan Universitas diharapkan memberikan pembekalan tentang rekomendasi seperti pemberian sosialisasi mengenai strategi self regulated learning yang efektif dari pihak profesional agar dapat mempertahankan dan meningkatkan kemampuan self regulated learning pada mahasiswa remaja akhir.

Saran bagi peneliti selanjutnya antara lain peneliti selanjutnya diharapkan mampu meningkatkan jumlah subjek yang berasal dari berbagai fakultas, dapat meneliti perbedaan prestasi akademik, self regulated learning, dan konsep diri mahasiswa remaja akhir yang pernah menjadi Finalis Bali Pageants dengan mahasiswa biasa yang tidak pernah mengikuti ajang tersebut, serta peneliti selanjutnya diharapkan mempertegas item-item pada skala self regulated learning agar tercipta pernyataan yang lebih komprehensif dan sesuai dengan kondisi subjek penelitian.

\section{DAFTAR PUSTAKA}

Agustiani, H. (2009). Psikologi perkembangan: Pendekatan ekologi kaitannya dengan konsep diri dan penyesuaian diri pada remaja. Bandung: Refika Aditama.

Azwar, S. (2014a). Penyusunan skala psikologi edisi-2. Yogyakarta: Pustaka Belajar.

Azwar, S. (2014b). Reliabilitas dan validitas. Yogyakarta: Pustaka Pelajar.

Azwar, S. (2014c). Dasar-dasar psikometri. Yogyakarta: Pustaka Belajar.

Chairiyati, L. R. (2013). Hubungan antara self-efficacy akademik dan konsep diri akademik dengan prestasi akademik. Humaniora, 4 (2), 1131-1132.

Cooley, C. H. (1902). Human nature and the social order. New York: The Scribner Press
De Porter, Bobbi, Mike Hernacki. (2003). Quantum learning. Bandung: Kaifa.

Efendi, K. (2004). Hubungan antara konsep diri dan kemampuan verbal dengan prestasi belajar pada siswa kelas lima Sekolah Dasar Muhammadiyah Sukonandi Yogyakarta. Indonesian Psychological Journal. 1 (1), 26-27.

Feist, J., \& Feist, G. J. (2010). Teori kepribadian. Jakarta: Salemba Humanika.

Ghozali, I. (2005). Aplikasi analisis multivariate dengan program SPSS. Semarang: Badan Penerbit Universitas Diponegoro.

Hurlock, E.B. (1980). Psikologi perkembangan: suatu pendekatan sepanjang rentang kehidupan edisi kelima. (terjemahan: Istriwidayanti \& Soedjarwo). Jakarta: Erlangga.

Puspita, S. A. (2016). Studi Pendahuluan: Kendala akademik mahasiswa Fakultas Kedokteran Universitas Udayana yang menjadi Finalis Bali Pageants. Denpasar: Tidak dipublikasikan.

Puspita, S. A. (2016). Studi Pendahuluan: Penjelasan ajang Bali Pageants. Denpasar: Tidak dipublikasikan.

Putri, P. R. (2015). Hubungan antara self regulated learning dan kelekatan remaja awal terhadap ibu dengan prestasi belajar siswa SMPN 6 Denpasar. (Skripsi Tidak Dipublikasikan). Program Studi Psikologi Fakultas Kedokteran Universitas Udayana

Siregar, R. (2006). Pengaruh indeks prestasi kumulatif dan persepsi mahasiswa akuntansi kota Medan mengenai beberapa faktor tertentu terhadap pilihan karir (Tesis Publikasi). Universitas Sumatera Utara Medan. 15-16.

Slavin, R. E. (2011a). Psikologi pendidikan edisi kesembilan jilid 1: Teori dan praktik. Jakarta: PT Indeks.

Slavin, R. E. (2011b). Psikologi pendidikan edisi kesembilan jilid 2: Teori dan praktik. Jakarta: PT Indeks.

Sugiyono. (2014). Metode penelitian kombinasi (mixed methods). Bandung: Alfabeta.

Suryabrata, S. (1993). Psikologi kepribadian. Jakarta: Raja Grafindo Persada.

Syah, M. (2014). Psikologi pendidikan dengan pendekatan baru. Bandung: PT Remaja Rosdakarya.

Syawal, G. (2010). Kompetensi guru. Medan: Unimed.

Wayan Windia. (2010). Peraturan Akademik Universitas Udayana. Jimbaran: Universitas Udayana.

Wolters, C. A., Pintrich, P. R., \& Karabenick, S. A. (2003). Assessing Academic Self-regulated Learning. Indicators of Positive Development: Definitions, Measures, and Prospective Validity, (pp. 8-30).

Wormer, K. V. (2011). Human behavior and the social environment: Second edition. New York: Oxford University Press.

Zimmerman, B. J., \& Schunk, D. H. (1989). Self regulated learning: from teaching to self-reflective practice. New York: The Guilford Press.

Zimmerman, B. J., Bonner, S., \& Kovach, R. (1996). Developing self regulated learners: Beyond achievement to self efficacy. Washington: American Psychological Association. 